\title{
THE CHILDREN IN THE MACEDONIAN TORT LAW
}

\author{
Neda ZDRAVEVA \\ Associate Professor \\ Iustinianus Primus Law Faculty, Ss. Cyril and Methodius University \\ E-mail: n.zdraveva@pf.ukim.edu.mk
}

\begin{abstract}
The position of the children in the tort law is a very specific one. It is a fact that a child could physically cause a damage to the property or to the immaterial values of someone else. However, it is also a fact that in the different stages of the mental development of a child, their understanding of their own conduct and the consequences thereof varies. On the other hand, once the damage has occurred it cannot be left uncompensated for. The injured party should not suffer the consequences of the acts of someone else. So, a question rises who will be liable for the damage. In the same time a child may suffer a damage to their property but more often to their person and personal rights, especially to their right to life and health. The consequences of such damage may not be the same as the one an adult may experience. Here we have a question on how this damage will be treated by the law.

The Macedonian tort law provides answers to these questions. The objective of this research is to analyse what is the position of the children in the cases of non-contractual liability for damage and is the law providing for sufficient mechanisms for protection of their rights. The solutions present in the national law are compared and analysed vis-à-vis the ones that exist in the states of former SFRY, having in mind the same legal tradition. In regard to the liability for damage the rules of the German and the French law as specific models for the liability for damage in the civil law system. The author concludes that the existing mechanisms on the Macedonian tort law system provide for adequate and sufficient protection of children in torts.
\end{abstract}

Key words: liability of minors, liability of parents, liability of supervisors of minor, damage, strict liability, faut-based liability, Macedonian tort law 


\section{Introduction}

The position of the children in the tort law is a very specific one. It is a fact that a child could physically cause a damage to the property or to the immaterial values of someone else. However, it is also a fact that in the different stages of the mental development of a child, their understanding of their own conduct and the consequences thereof varies. On the other hand, once the damage occurred it cannot be left uncompensated for. The injured party should not suffer the consequences of the acts of someone else. So, a question rises who will be liable for the damage. In the same time a child may suffer a damage to their property but more often to their person and personal rights, especially to their right to life and health. The consequences of such damage may not be the same as the one an adult may experience. Here we have a question on how this damage will be treated by the law.

The obligations arising from damage (civil wrongs, torts) are "such relations wherefrom for the party of the tortfeasor arises obligation to compensate the damage, while for the injured party the right the damage to be compensated" (Galev \& Dabovikj Anastasovska, 2008, p. 583). The specific position of the children in these relations has been regulated in the Macedonian law on obligations since the federal Law on Obligations. ${ }^{1}$ When the national Law on Obligations in 2001 was enacted it contented the same provisions, but its further amendments provided, in our opinion, certain clarifications. ${ }^{2}$ The Law provides for rules regarding the two parties of an obligation - when a child causes a damage and when a damage is caused to a child. In regard to the first situation, we will see under which conditions the child will be liable for the damage and where the liability is born by another person, primarily the parents, or persons that exercise supervision over the minor. In the second part of the paper, we will analyse the legislation protecting the minor as an injured party and the rights of the minor to have the damage suffered compensated.

\section{Children as tortfeasors}

The basic rule of the liability for damage is that the person who causes the damage is liable to compensate for it. ${ }^{3}$ This rule is based on the assumption of tortious capacity, that "the person who caused the damage was able to understand the meaning of their action in terms of whether it is contrary to the law and whether it causes harm to another person and is aware of the potential consequences of their conduct" (Zhivkovska, 2004, p.69-72). The tortious

1 Law on Obligations ("Official Gazette of Socialist Federative Republic of Yugoslavia" no. 29/78, 39/85 and 57/89); hereinafter: LOO/SFRY

${ }^{2}$ Law on Obligations („Official Gazette of the Republic of Macedonia” no.18/2001; 4/2002; 5/2003; 84/2008; 81/2009 and 161/2009); hereinafter: LOO

${ }^{3}$ Art. 141, para. 1, LOO; translations of legislative texts from Macedonian language, Serbian language, Croatian language, Montenegrin language and Slovene language were done by the author 
capacity is possessed only by those persons who are able to understand the consequences of their actions, both acts and omissions, and therefore are held accountable for them. It follows that not all persons capable of causing harm may be held liable. Persons who cannot comprehend their actions will appear as a de facto tortfeasor, while those who will be held liable as a legal tortfeasor. In practice, the actual tortfeasor is often the legal tortfeasor, but it is not uncommon for them to be two different persons. Simply put, persons who do not meet the conditions prescribed by law for acquiring tortious capacity are not liable for the damage they cause. In principle, there are two such cases: when the damage is caused by a mentally incompetent person and when the damage is caused by a minor.

In the cases when the damage is caused by a person considered a minor by the national law, the system of liability will depend on the age of the minor. As a rule, in the civil law systems, liability of children is excluded or restricted. Due to the age of the minor, it is considered that they are unable to meet the objective standard of care. However, there is a difference in the approach. In some of the systems, as is the case with the Macedonian Law on Obligations, the capacity to understand the potential consequences of their conduct is a distinct requirement for fault liability. Consequently, the standard of care is the same for everyone and one who is not able to meet that standard of care due to age (or mental incapacity) cannot be held liable. On the other hand, there are systems where the standard of care is lowered in response to the age of the person, but then the conduct is compared to the one that may be expected from persons in the same age group (Werro \& Palmer \& Hahn, 2004, p.389). There are, however, differences in the determination of the relevant age limits. In the Macedonian law it is considered that a person has tortious capacity, thus is liable for damage, when he /she reaches the age of fourteen, before which age a minor cannot be held liable for damage. Still, the position is different if the minor is under the age of seven or between seven and fourteen years of age.

\subsection{The position of the minor}

The Macedonian Tort Law holds a clear distinction concerning a minor up to the age of seven not having tortious capacity and therefore that person will not be held accountable for the damage caused. ${ }^{4}$ This position of the law comes from the fact that minors up to seven years of age are considered to be unable to understating their actions and consequences thereof. The position of the Macedonian legislature can be seen in the comparative law as well. Following the position found in the Yugoslav Law on Obligations, the laws on obligation of the other successor states, Law on Obligation in Croatia ${ }^{5}$, Serbia ${ }^{6}$, Bosnia

\footnotetext{
${ }^{4}$ Article 147, para. 1, LOO

5 Article 1051, para. 1, Law on Obligations ("Official Gazette of the Republic of Croatia” 35/05, 41/08, 125/11, 78/15, 29/18), hereinafter: LOO/Hr

${ }^{6}$ Article 160, para. 1, Law on Obligations ("Official Gazette of SFRY" no. 29/78, 39/85, 45/89, "Official Gazette of Federal Republic of Yugoslavia" no. 31/93,
} 
and Herzegovina ${ }^{7}$, Montenegro ${ }^{8}$ and Slovenia ${ }^{9}$ have the same provision as LOO stipulating "A minor up to the age of seven is not liable for the damage he/she will cause.". This would mean that under no circumstances will the child would be held accountable. On the other hand, liability of children from the age of seven to age of fourteen may exist. The principal rule of Article 147, para. 2, LOO states, "A minor from the age of seven to the age of fourteen is not liable for damage, unless it is proven that he was capable of reasoning in causing the damage". This is practically an assumption, that may be rebutted, they are not liable for damage. The person, that has an interest in having the minor liable for the damage, in this case, should prove that he/she was capable of reasoning in causing the damage. The same rule exists in the laws of the former SRFY states. ${ }^{10}$ Finally, LOO provides that "A minor over the age of fourteen shall be liable in accordance with the general rules for liability for damage". ${ }^{11}$

This two-scale system of the liability of and for minors, as we will elaborate further, is very specific form of regulating the issue in the comparative European tort law. Minors up to age of seven are not liable in the German Law where $\S 828$, para. 1 of the German Civil Code ${ }^{12}$ provides that "A person who has not reached the age of seven is not responsible for damage caused to another person". A further stratification point in the German Law is the age of ten. Thus, as per $\S 828$, para. 2 and 3, BGB "(2) A person who has reached the age of seven but not the age of ten is not responsible for damage that he inflicts on another party in an accident involving a motor vehicle, a railway or a suspension railway. This does not apply if he intentionally caused the injury. (3) A person who has not yet reached the age of eighteen is, to the extent that his responsibility is not excluded under subsection (1) or (2), not responsible for damage he inflicts on another person if, when committing the damaging act,

"Official Gazette of Serbia and Montenegro" no. 1/2003, "Official Gazette Republic of Serbia" no.18/2020), Hereinafter: LOO/Sr

${ }^{7}$ Article 160, para. 1, Law on Obligations of the Federation of Bosnia and Herzegovina ("Official Gazette of SFRY" no. 29/78, 39/85, 45/89, "Official Gazette of the Republic of Bosnia and Herzegovina" no. 2/1992, 13/1993 and 13/1994 and "Official Gazette of the Federation of Bosnia and Herzegovina" no. 29/2003 and 42/2011); hereinafter: $\mathrm{LOO} / \mathrm{BiH}$

8 Article 153, para. 1, Law on Obligations ("Official Gazette of Montenegro" no. 47/2008, 4/2011, 22/2017); hereinafter: LOO/Cg

${ }^{9}$ Article 137, para.1, Code of Obligations ("Official Gazette of Republic of Slovenia" no. 97/07, official consolidated version 64/16 - decision of the Constitutional Court 20/18 - OROZ631); hereinafter LOO/S1

${ }^{10}$ Article 1051, para 2, LOO/Hr; Art. 160, para 2, LOO/Sr; Art. 160, para 2, LOO/BiH; Article 153, para. 2, LOO/Cg; Article 137, para.2, LOO/S1

${ }^{11}$ Article 147, para 3, LOO. Same provision is found in Article 1051, para 2, LOO/Hr; Art. 160, para 2, LOO/Sr; Art. 160, para 2, LOO/BiH; Article 153, para. 2, LOO/Cg; Article 137, para.2, LOO/Sl

${ }^{12}$ Bürgerliches Gesetzbuch in der Fassung der Bekanntmachung vom 2. Januar 2002 (BGB1. I S. 42, 2909; 2003 I S. 738), das zuletzt durch Artikel 10 des Gesetzes vom 30. März 2021 (BGBl. I S. 607) geändert worden ist; hereinafter: BGB 
he does not have the insight required to recognise his responsibility". This solution in the German law is similar, except for the age, as the one existing in the Macedonian law. The legislation recognizes that there might be a possibility the minor understands his/her conduct and the consequences thereof, but only when it involves an accident involving a motor vehicle, a railway or a suspension railway that was caused intentionally. Minors older than ten years of age will be exempt from liability if they do not have the (mental) capacity to understand their actions. The French Code Civil does not contain a provision with explicit reference to the age, however it provides rules for the liability of the parents, for children under their authority - children up to 18 years of age (Fabre-Magnan, 2004, p.72-73).

\subsection{If not the minor, then who?}

The physical capability of children to cause harm is undisputed. The level of their mental development precludes them to understand the potential consequences of their conduct, so the law responds to this excluding or limiting their liability. As a principle, however, the damage that occurred may not be left uncompensated. The solution found by the law is locating the liability for damage in the parents of the minor and/or the person that was responsible for their supervision. The Law on Obligations operates with the term parents, to be understood as any person who has a parental authority over the minor being parent by birth or adoption ${ }^{13}$. The plurality of the term is because of the position of the Macedonian Family law that the parental rights and obligations concerning a child belong both to the mother and the father. ${ }^{14}$ On which grounds the parents/supervisors will be held liable for the damage caused by the minor will primarily depend on the age of the child. However, there are cases when even if the minor is to be considered liable, the damage is compensated by the parent and vice versa when the minor is not considered liable due to lack of tortious capacity but the damage is compensated from his/her property, when the principles of equity deem so to be.

When it comes to the liability for damage caused by children up to the age of seven, the parent will be liable "regardless of their fault". ${ }^{15}$ This provision of the law provides for 'strict' or 'objective' liability of the parents for the acts of their children. The strict liability, generally related with liability for dangerous objects and the activities, in the wider sense of the Macedonian, and former SFRY, law would mean that the conduct of the parent would not have any influence on their liability. The parents will be liable if the general conditions for liability for damage are met, meaning there is a damage, material or

${ }^{13}$ See Article 7, Law on Family ("Official Gazette of the Republic of Macedonia" no. 153/2014, 104/2015 and 150/2015); hereinafter: LF

${ }^{14}$ See Article 45, LF

${ }^{15}$ Article 152, para. 1, LOO; same rule is found in Article 1056, para 1, LOO/Hr; Art. 165, para 1, LOO/Sr; Art. 165, para 1, LOO/BiH; Article 158, para. 1, LOO/Cg; Article 142, para.1, LOO/Sl 
immaterial, the act that caused the damage was direct and contrary to the law and there is a causal link between the act and the damage. In the cases of strict liability, the existence of the causal link is presumed. From a practical point of view, there will be no need to demonstrate that the parents were negligent in their performing their parental duties.

This, on the other hand side, means that the only possibility for parents' liability to be excluded is if they prove that there is no causality between the damage and the act, as per the rules of strict liability ${ }^{16}$. This will be a case when damage was a result of: 1) an act (or omission) of the injured party, 2) an act of a third party or 3) a force majeure. ${ }^{17}$ When it comes to the rebutting of the presumption of causal link, the other former SFRY states view the situation differently. In Slovenia ${ }^{18}$, Montenegro ${ }^{19}$, Bosnia and Herzegovina ${ }^{20}$, Serbia ${ }^{21}$ and Croatia ${ }^{22}$ there is more general provision providing that the parents' liability will be excluded in cases where it is proven that the damage is not a result of the act of the child in the case. ${ }^{23}$ Until 2008 the same provision existed in the Macedonian legislation. In 2008 it was decided to amend the provision to specify when the damage would be considered not to be a result of the dangerous object or activity ${ }^{24}$. The provision regarding the exclusion of the liability in the cases of strict liability ${ }^{25}$ specifies this further. Thus, there will be no liability if the damage that the injured party suffers is a result of 1) an action that could not have been foreseen, nor avoided or removed, which constitutes a force majeure $^{26}$ and 2) an action of the injured party or a third party, which tortfeasor (in the case the parent) could not have foreseen and whose consequences he could not have avoided either remove. Further, there will be partial exclusion of the liability if the injured party partially contributed to the occurrence of the damage. In cases when a third party has partially contributed to the occurrence of the damage, the third party will be jointly and severally liable to the injured person with the tortfeasor to the to the proportion of their fault. ${ }^{27}$ When it comes to the liability for children over the age of seven, the

\footnotetext{
${ }^{16}$ Article 152, para 2, LOO

${ }^{17}$ Article 159, LOO

18 Article 149, LOO/S1,

${ }^{19}$ Article $168, \mathrm{LOO} / \mathrm{Cg}$

${ }^{20}$ Article 173, LOO/BiH

${ }^{21}$ Article 173, LOO/Sr

22 Article 1063, LOO/Cr

${ }^{23}$ The provision in all laws is the same reading: "Damage caused in connection with a dangerous thing, i.e. dangerous activity, is considered to originate from that thing, i.e. activity, unless it is proven that they were not the cause of the damage."

${ }^{24}$ Article 48 of the Law on amendments on the Law on Obligations ("Official Gazette of the Republic of Macedonia" no. 84/08)

${ }^{25}$ Article 163/LOO

${ }^{26}$ See Article 252/LOO

${ }^{27}$ Same rule exists as Article 1067, LOO/Hr; Art. 177, LOO/Sr; Art. 177, LOO/BiH; Article 177, LOO/Cg; Article 153, LOO/S1
} 
liability of the parents is governed by the regime of fault-based liability. As per Article 152, para. 4, parents are liable for the damage caused by their child who has reached the age of seven, unless they prove that the damage arose through no fault of their own ${ }^{28}$. This concept corresponds to the position that minors over the age of seven could be found liable for damage on their own. However, in the cases when it is found that the minor was not capable to understand the meaning of their conduct and the consequences thereof, the parent will be liable. It will be considered that the parents' negligence led to the occurrence of damage, unless they provide that they were acting with the expected standard of care ${ }^{29}$. When the parent is liable together with the child for the child's actions, their liability is joint and several ${ }^{30}$. The regime of the foundations of the liability is different in France and in Germany. The French model foresees strict liability of the parents, as it is seen as a vicarious liability (Fabrre-Magnan, 2004, p. 74). Contrary, in the German Law there is no strict liability of the parents or any sort of vicarious liability. Instead, the parents are only liable for the negligent fulfilment of their duty to supervise (Brüggemeier, 2004. p.88)

In addition, to the general rules on the exclusion of liability under the strict liability regime, there are specific rules on exclusion of the parents' liability by its attribution to the person that had supervision over the child in the moment the damage occurred (Article 153, para 3, LOO) ${ }^{31}$. As per Article 154, para. 1 of LOO, when a minor is under the supervision of a guardian, school or other institution, and causes damage while under supervision, the supervisor will be liable for the damage unless they prove that they performed the supervision in the manner as they were responsible to, meaning they applied due care, or that the damage would occur in spite of the careful performance of the supervision, or in spite of applying diligent care. ${ }^{32}$ In principle this would mean that the supervisor should provide that there was not a negligence on their side. The LOO, however foresees one more situation where the supervisor may be exempt from the liability for damage even if the damage occurred when the minor was under their supervision. Thus, as per Article 155 of LOO, the injured party will have the right to claim compensation from the parents when the damage was caused because of the poor upbringing of the minor, the bad

${ }^{28}$ Article 152, para. 4, LOO; same rule is found in Article 1056, para 4, LOO/Hr; Art. 165, para 4, LOO/Sr; Art. 165, para 4, LOO/BiH; Article 158, para. 4, $\mathrm{LOO} / \mathrm{Cg}$; Article 142, para.4, LOO/S1

${ }^{29}$ See Article 145 in relation to Article 11 of the LOO; same rule in found in in Article 1049 in relation to Article 10, LOO/Hr; Art. 158 in relation to Article 18, $\mathrm{LOO} / \mathrm{Sr}$; Art. 158 in relation to Article 18, LOO/BiH; Article 152 in relation to Article 11, $\mathrm{LOO} / \mathrm{Cg}$; Article 135 in relation to Article $6 \mathrm{LOO} / \mathrm{Sl}$

${ }^{30}$ Article 153, LOO; same rule is found in Article 1057, LOO/Hr; Art. 166, LOO/Sr; Art. 166, LOO/BiH; Article 159, LOO/Cg; Article 143, LOO/Sl

${ }^{31}$ Same rule is found in Article 1056, para 3, LOO/Hr; Art. 165, para 3, LOO/Sr; Art. 165, para 3, LOO/BiH; Article 158, para. 3, LOO/Cg; Article 142, para.3, $\mathrm{LOO} / \mathrm{Sl}$

${ }^{32}$ Same rule is found in Article 1058, LOO/Hr; Art. 167, LOO/Sr; Art. 167, LOO/BiH; Article 160, LOO/Cg; Article 144, LOO/Sl 
examples or the vicious habits given to him by his parents, or if the damage can be attributed to the fault of parents in any way. If the supervisor has redressed the damage, they are entitled to request recovery of the amount paid, from the child's parents. ${ }^{33}$

When it comes to the liability for damage caused by children and its compensation, the LOO provides for the possibility of compensation on grounds of equity. As per Article 156, if the damage is caused by inter alia, a child and the compensation cannot be obtained from the person having a duty to supervise, the court may order the compensation to be paid by the child (from their property) should equity so require and particularly having in mind the material situation of the tortfeasor and the person suffering damage. In cases where the damage is caused by a minor who has the tortious capacity but they are unable to redress it, the court may, having in mind the principles of equity and the material situation of parents and the injured person, oblige the parents to pay compensation of that damage. ${ }^{34}$

\section{Children as injured party}

The rights of the children are guaranteed by international instruments and national law. From the perspective relevant to the tort law, the Convention for the Rights of the Children guarantees that any child, understood as person up to the age of 18 (Article 18), has the right to life (Article 6); expression (Article 13); privacy, honour and reputation (Article 16). The protection of their rights, as well as the right to property and in personal rights in general is inter alia, guaranteed by the Law on Obligations that provides civil law remedies in the case of their breach. These remedies are available to every natural person, including children. Thus, Article 9-a, para. 1 of LOO, provides that every natural person, in addition to the protection of property rights, has the right to protection of his personal rights in accordance with the law. The LOO (Article 9-a) does not have an exhaustive list of personal rights and provides that they are to be understood as the rights of life, physical and mental health, honour, reputation, dignity, personal name, privacy of personal and family life, freedom, intellectual creation and other personal rights.

The Law on Obligations provides for protection of a person suffering damage when the damage occurred directly and/or indirectly. In the first case, the damage is a result of an action (or omission) directed toward the property or the personal rights of the injured person. In the second case, the damage that the person suffers is a result of damage that has been directly inflicted to another person to whom the injured party is in close relation. In both cases the injured persons can suffer material and immaterial damage. The violation of the

\footnotetext{
${ }^{33}$ Same rule is found in Article 1059, LOO/Hr; Art. 168, LOO/Sr; Art. 168, LOO/BiH; Article 161, LOO/Cg; Article 145, LOO/S1

${ }^{34}$ Same rule is found in Article 1060, LOO/Hr; Art. 169, LOO/Sr; Art. 169, LOO/BiH; Article 162, LOO/Cg; Article 146, LOO/S1
} 
personal rights of the children may lead both to immaterial and to material damage.

\subsection{Material Damage to Children}

According to Article 142 of LOO a person may suffer material damage understood as reduction of someone's property (simple damage/loss), the prevention of its increase (lost benefit) and immaterial damage understood as violation of their personal rights. The violation of the personal rights, however, may also cause material damage, especially when it comes to damage arising from loss of a close person or relative damage is caused to the health of the child.

As nothing in the national law precludes the children from owning property, when, due to an act or an omission, the value of the property decreases, as well as when the wrongful act prevents an increase in the value of the property, material damage will occur. In these cases, as a primary rule. the tortfeasor is liable to re-establish the situation existing prior to the occurrence of damage (natural restitution). ${ }^{35}$ When such re-establishment of the previous situation fails to eliminate the damage entirely, or the restitution is impossible, or the court finds it necessary for the responsible person to pay monetary compensation, the damage will be compensated by payment of an adequate amount of money as compensation for loss. ${ }^{36}$ In addition, the court may award compensation in money, at the request of the person suffering damage, unless the circumstances of the specific case justify restitution ${ }^{37}$. When it comes to the scope of the compensation ${ }^{38}$ of the simple damage, the amount to be paid is determined according to prices at the time of the rendering of the court's decision, unless something else is ordered by law. In assessing the amount of the profit lost, the child would be entitled to the profit which was reasonably expected according to the regular course of events or particular circumstances, and whose realization has been prevented by an act or omission of the tortfeasor shall be taken into account. The same rules are applicable in all of the former SFRY states. ${ }^{39}$

Specific situation regulated by the Law on Obligation is the material damage due to loss of a close person. In the event of the death of a close person (relative), the family members are entitled to reimbursement of the usual costs of their funeral (Article 182, para. 1, LOO), costs of the treatment of injuries sustained, as well as the earnings lost due to the inability to work. (Article 182,

${ }^{35}$ Article 174, para. 1, LOO

${ }^{36}$ Article 174, para. 2 and 3, LOO

${ }^{37}$ Article 174, para. 4, LOO

${ }^{38}$ Article 178, para. 2 and 3, LOO

${ }^{39}$ See Articles 1085 and 1089, LOO/Hr; Articles 185 and 189, LOO/Sr; Articles 185 and 189, LOO/BiH; Articles 192 and 196, LOO/Cg;0 Article 164 and Article $168, \mathrm{LOO} / \mathrm{Sl}$ 
para. 2, LOO). Law on Obligations takes into account the fact that with the loss of a person who provides support in a family, the means for the uninterrupted existence of that family are reduced. Therefore, LOO, in Article 183, para. 1 entitles the person who was supported or regularly assisted by the deceased, as well as the one who according to the law had the right to seek support from the deceased, to be compensated for the damage suffered by the loss of support. The circle of persons who have the right to support is defined by the Family Law and includes the minor children, including the children who are in process of education up to 26 years old ${ }^{40}$ as well as adult (child) who is incapable of work due to illness, physical or mental disability, and does not have sufficient means of subsistence and cannot receive them from his property, while that incapacity lasts (Article 179, para. 3, LF). According to the Law on Obligations, the damage caused by the loss of financial support is compensated in a form of a monetary annuity. The amount of the annuity is assessed in view of all circumstances of the case, and it cannot be higher than the one that the injured party would have received from the deceased if they had survived (Article 183, para. 3, LOO). ${ }^{41}$ The same rules are applicable in all of the former SFRY states. ${ }^{42}$

A child has a right to compensation of the damage that occurred due to injury or any other detriment to health. As per Article 184, LOO, this would include reimbursement of the costs of treatment and others necessary expenses in connection therewith, as well as earnings lost due to inability to work during treatment. The compensation of the lost earnings will be relevant only for children who under the Labour Law have the right to work and earnings. ${ }^{43}$ The injury may result in complete or partial inability to work due to which there will be (a future) loss of earnings, or in permanent increase of needs or destruction or reduction of opportunities for further development and advancement, in which case, the tortfeasor will be obliged to pay monetary annuity as a

${ }^{40}$ Article 179, para. 1 and 2, LF

${ }^{41}$ This regulation of the amount of the annuity in the LOO, suggests that when assessing it the court should also take into consideration the provisions of the Family Law that refer to determining the amount of alimony. See Article $195-197$, LF.

${ }^{42}$ See Articles 1093 and 1094, LOO/Hr; Articles 193 and 194, LOO/Sr; Articles 193 and 194, LOO/BiH; Articles 200 and 201, LOO/Cg; Articles 172 and173, $\mathrm{LOO} / \mathrm{Sl}$.

${ }^{43}$ Article 18: Capacity to conclude employment contract with a young person under 18 years of age, Law on Labour Relations ("Official Gazette of the Republic of Macedonia" nos. 62/2005, 106/2008, 161/2008, 114/2009, 130/2009, 149/2009, 50/2010, 52/2010, 124/2010, 47/2011, 11/2012, 39/2012, 13/2013, 25/2013, 170/2013, 187/2013, 113/2014, 20/2015, 33/2015, 72/2015, 129/2015, 27/2016 and 120/2018 and "Official Gazette of the Republic of North Macedonia" nos. 110/2019 and 267/2020). 
compensation for that damage (Article 184, para. 2) ${ }^{44}$. In these cases, the compensation is determined, as a rule in the form of a monetary annuity, for life or for a specified time. This monetary annuity, in principle, is paid monthly in advance, unless the court determines otherwise (Article 177, para. 1 and 2, $\mathrm{LOO})^{45}$. Once the amount of the annuity is determined by the court it may be changed upon a request of the injured party (now as creditor) or the tortfeasor (now as debtor), if there is a significant change of the circumstances. The creditor may request the annuity to be increased, especially if future damage occurs, while the debtor may request the amount to be reduced or the payment to be stopped (if, for example, the consequences of the injury has ceased to exist) ${ }^{46}$ The entitlement to monetary annuity is a personal right and cannot be transferred to another person. By an exception, the due amounts may be transferred to another, if the amount of compensation is determined by a written agreement of the parties or by a final court decision. ${ }^{47}$ The issue of the right of a monetary annuity in case of a material damage as a result of bodily injury or damage to health, as well as the rules on the calculation, changes and transfer of the monetary annuity are also regulated in the laws of the former SFRY states in the same manner as in the Macedonian LOO.

\subsection{Immaterial Damage to Children}

The immaterial damage in the Macedonian law is defined as breach of personal rights (Article 142, LOO). This concept was introduced in the Macedonian tort law with the amendments of the Law on Obligations in 2008. The new, objective, concept of the immaterial damage departs from the position that the immaterial damage is a subjective notion. By the subjective concept, in order for an occurrence of immaterial damage to be considered, the injured party should to feel the consequences in form of pain and suffering. According to the accepted objective concept, the degree to which the injured party can feel the pain and suffering is not important for the establishment of the right to be compensated for the damage, and it is only relevant for the amount of compensation. Although, it should be noted that the tendencies of the objective

${ }^{44}$ See Articles 1093 and 1094, LOO/Hr; Articles 193 and 194, LOO/Sr; Articles 193 and 194, LOO/BiH; Articles 200 and 201, LOO/Cg; Articles 172 and173, $\mathrm{LOO} / \mathrm{Sl}$.

${ }^{45}$ As per Article 177, para. 3 -5, LOO, the injured party, now as a creditor, has the right to request the necessary collateral for the payment of the annuity, unless that, according to the circumstances of the case, would not be justified. If the tortfeasor, now as a debtor, does not provide the collateral determined by the court, the injured party has the right to demand that a total amount be paid to them instead of annuity. The total amount is determined by the amount of monthly annuity and the probable duration of the life of the creditor, by deducting the appropriate interest. If serios reasons exist, the creditor may also request the total amount of annuity to be paid immediately or later.

${ }^{46}$ Article 185, LOO.

${ }^{47}$ Article 185, LOO. 
concept are that entitlement to compensation should also be given to persons who cannot feel the pain at all (for example they are in a coma) or if, because of their mental state, they are not able to see the significance of the condition in which they are (Crnić, 2006, p.102). This concept exists in the legislation of Croatia and Montenegro as well. ${ }^{48}$ The other states, kept the concept of immaterial damage defined as "inflicting physical or mental pain or fear on another." 49 When it comes to the other issues of the liability for immaterial damage and the methods of its compensation, as elaborated below, the rationale of the provisions of the Laws on Obligation in the other states are the same as in the Macedonian law. ${ }^{50}$

Immaterial damage may occur in particular, and most frequently, by violation of physical and mental health ${ }^{51}$ and results in the right to compensation. The injury to physical and mental health, in terms of liability for immaterial damage is actually reflected in the occurrence of physical and mental pain. The conditions for compensation for the immaterial damage that occurred are the severity of the injury and circumstances of the case. What is specific is that the intensity and duration of these pains will be qualifying circumstances in determining the amount of fair monetary compensation, as will be discussed further. The right to compensation of the immaterial damage also belongs to a conceived and unborn child (foetus, nasciturus) in case the child is born alive and the damage is directly to the child. If due to the wrongful act. the foetus terminates, then the specific rules related to liability for the death of a close person will be applied, as elaborated further. In this regard, considering the relevant for damage to children due to their age and life expectancy, it is important to note that LOO also provides for the possibility an equitable fair monetary compensation to be awarded for the future immaterial damage, if according to the regular course of events, it is certain that the damage will last into the future ${ }^{52}$. A child enjoys protection of their other personal rights including the right to honour and reputation and privacy. When it comes to the protection of the honour and reputation, there is a duality in the national tort law system, as that right is protected by the Law on Obligations as well as by the Law on Civil Liability for Insult and Defamation, ${ }^{53}$ which regulates civil liability for damage inflicted on the honour and reputation of a natural person (or a legal entity) by an insult or defamation. This right belongs to any person that will suffer damage, although the manner in which the subject-matter is regulated it is to be improved (Zdraveva, 2018, p. 273).

${ }^{48}$ Article 1045 in relation to Article 19, LOO/Hr; Article 149 in relation to Article 207, $\mathrm{LOO} / \mathrm{Cg}$.

49 Article 155, LOO/Sr; Article 132, LOO/Sl; Article 155, LOO/BiH

${ }^{50}$ See Articles 199-203, LOO/Sr; Articles 199-203, LOO/BiH; Article 178-180, LOO, LOO/Sl; Article 210a and 210b, LOO/Cg; Article 1100 and 1101, LOO/Hr.

${ }^{51}$ Article 142 in relation to Article 9-a, para. 2, LOO

52 Article 192, LOO

${ }^{53}$ Law on Civil Liability for Insult and Defamation („Official Gazette of the Republic of Macedonia" no.143/2012) 
The Law on Obligations specifically regulates the case of immaterial damage sustained due to death or severe disability of a close person or family member. In the comparative case law, which is relevant to the same rationale of the provisions, severe disability is considered "a change in the body of the injured party that causes repulsion, pity and other negative reactions in the environment, due to which the family members are exposed to daily care and enduring the pain that the injured party suffers as a consequence of the damage to his bodily integrity" (Judgment of the Supreme Court of Serbia, Rev.2261/98 of 20.05.1998). Particularly severe disability is not only reflected in the sphere of physical integrity and functionality, but also in "the sphere of mental functions when due to severe brain damage there is a decline in the psychological trauma and reduction of the mental and intellectual functions to the extent that life and ability to work is reduced to $10 \%$, although there are no visible external manifestations of particularly severe disability" (Judgment of the Primary court in Bjelovar, Gz. no. 281/91 of 09.01.1992). In this case the child may be the injured party if the death or severe disability happened to a close person of the child.

On the other hand, the family members of the child may be the injured party if due to wrongful act the child dies or sustains severe disability. The LOO provides for the right the immaterial damage to be compensated in general terms covering both of these situations. Thus, according to Article 190 of the LOO, this right primarily belongs to the members of the immediate family of the directly injured party (children, spouse and parents). Further, there will be entitlement to damage compensation to the brothers, sisters and the extramarital partner, as well as the grandparents and grandchildren who lived with the deceased or injured person in a more permanent life community. The parents are also entitled to a fair monetary compensation in case of loss of a conceived and unborn child. When it comes to rights of the parents, the goals and functions of the provision are clear. It should be noted that in practice the parental relationship is valued depending on the factual situation, i.e., when there is a permanent living community, this group includes persons who care as parents even though they do not formally have parental rights. Thus, "the stepfather also has the right to compensation for emotional pain due to the death of the stepson, if there was a permanent community of life between them with a close emotional connection with material fear of each other, all valued as part of other relationships established in the community of life"(Judgement of the Supreme Court of the Republic of Macedonia, Rev. no. 274/93 from 8.04.2003).

The right of children to "equitable monetary compensation", the term used by the LOO to identify the pecuniary compensation of the immaterial damage, in the event of death or particularly severe disability has existed in the system established by the LOO/SFRY and the court practice in its application. Particular question presented for the courts' consideration has been whether compensation should be limited by the age of the child. Until the adoption of LOO/SFRY, the prevailing view was that the ability of the child to comprehend the meaning of the loss of close person was relevant. This is considered to occur around the sixth year of a child's life, with exceptions, around the fourth or fifth 
year. The loss refers only to death and not to a particularly severe disability. While the court takes into consideration, above all, the relationship that exists between the parent and the child, the emotional suffering that the child will have in the course of their development is relevant (Radišić, 2004, p. 289). According to the Judgment of the Supreme Court of the Republic of Macedonia (Rev. No. 139/97 of 08.07.1998) "Even children under six years of age, in case of the death of a parent, experiences severe psychological trauma through the inherent instinctual mechanism and emotions that will follow in their further development, due to which they are entitled to compensation for immaterial damage due to emotional pain.". The deliberations of the Civil and Civil-Trade divisions of the Federal Court, the Supreme Courts of the Republics and the Provinces and the Supreme Military Court from 15-16.10.1986 found that "The equitable monetary compensation for the suffering of a child caused by death of a parent is compensation for the pain caused by the cognizing of existence of death, as well as for all the later pains that the child suffers due to the loss of the parent - love, care and attention that the parent gives them, which belong to the child and which due to age could not be felt [by the child] due to death itself of the parent, because it is a matter of compensation for same type of damage". On the issue of siblings, the court insists on the existence of a more permanent living community. However, in the modern living conditions, in our opinion, the condition "more permanent living community" should be interpreted more broadly, in terms of existence of a stable and lasting emotional connection between persons and not a physical community of life.

The Macedonian Law has a general provision that immaterial damage is compensated via immaterial means (moral satisfaction) and material means (material satisfaction) in the cases provided by law $^{54}$. The primacy of the remedies is placed on moral satisfaction, because for material satisfaction ${ }^{55}$ special conditions should be met: the severity of the injury and the circumstances of the case. The moral satisfaction is provided as an announcement of the verdict, i.e., the correction, withdrawal of the statement with which the violation was committed, or something else that can achieve the goal achieved with the equitable monetary compensation. This form of satisfaction, as per the case law is most often related to the injuries of the personal rights to honour, reputation, privacy. Material satisfaction means awarding an equitable monetary compensation, a monetary amount which, as the title implies, aims at satisfaction and not compensation. This is evident from the provision of Article 189 that indicates that the court should take into consideration the purpose that the compensation serves. LOO provides for clear guidelines to the courts on what should be taken into account when determining the amount of equitable monetary compensation: 1) the strength and duration of the injury which caused physical pain, mental pain and fear, 2) the purpose which the compensation serves, and 3) that the compensation awarded is not contrary to aspirations that are not compatible with its nature and social

${ }^{54}$ Article 187-a, LOO

${ }^{55}$ Article 189, LOO 
purpose. The court, when deciding on the amount, will take into account the time elapsed from the occurrence of the damage to its adjudication, given that the right on equitable monetary compensation becomes due on the day the judgment becomes final. As per the Macedonian LOO the compensation for immaterial damage will be awarded when all conditions are met, regardless of the compensation for material damage, as well as in its absence. In addition to these rules, in accordance with Article 189, para. 4, LOO, in certain cases, when it is regulated differently by another law, the rules of that law will be applied. In the case law, these general provisions, which correspond to Article 200 of LOO/SFRY, are additionally elaborated ${ }^{56}$, which makes it clearer what criteria are taken into account when determining the amount of equitable monetary compensation.

\section{Conclusion}

The Macedonian tort law provides for comprehensive system protecting the rights of the children in obligations arising from damage. The issue of the liability of children is regulated, taking into account the specificities of the mental development of the children, but also the needs of the injured person to receive compensation for their damage. The system that exists is specific to the Macedonian law and the laws of the states of former SFRY that follow the same legal tradition. A child will under no circumstances be considered liable for damage if they are up to seven years of age. Their parents will be liable on basis of the rules for strict liability for damage. This enables adequate protection of the damaged person, as the grounds for exclusion of the parental liability are strict and related to objective circumstances. When it comes to the liability for children from the age of seven to age to age of fourteen, as a rule they are not considered liable but this is rebuttable. Their parents will be liable for the damage unless the due standard of paternal control existed. Children older than fourteen are considered liable, but based on the principle of liability for equity the damage may still be compensated from the parents. All of this together confirms the position that there are sufficient mechanisms to provide for liability for damage caused by children.

When children are the injured party, the law and the practice allow the different forms of damage that they may sustain to be compensated for. This includes not only damage to the property and the personal rights that has been inflicted directly to the child but also the damage that may arise as a result of death and injury to a close relative, as well as the damage that may arise in future. In the

56 See for example Judgment of the Supreme Court of the Socialist Republic of Macedonia, Rev. No. 283/80 of 17. 06. 1980; Deliberation of the Civil and Civil-Trade Divisions of the Federal Court, the Supreme Courts of the Republics and the Provinces and the Supreme Military Court, held on 1516.10.1986; Principle Position no. 3/85 established at the 28th Joint Session of the Federal Court, the Supreme Courts of the Republics and the Provinces and the Supreme Military Court, held on 6 and 7 November 1985 
same time the parents and close relatives are entitled to damage due to a loss of child or if the child suffers severe disability. We conclude that the existing mechanisms on the Macedonian tort law system provide for adequate and sufficient protection of children in torts.

\section{References}

\section{Books and articles}

Brüggemeier G. (2004). Case 1: Damaging acts of minors, Germany. Werro F., Palmer V.V., (eds.). The Boundaries of Strict Liability in European Tort Law. Durham: Carolina Academic Press

Crnić, I. (2006). Neimovinska šteta [Immaterial Damage]. Zagreb: Ogranizator Fabre-Magnan, M. (2004). Case 1: Damaging acts of minors, France. Werro F., Palmer V.V., (eds.). The Boundaries of Strict Liability in European Tort Law. Durham: Carolina Academic Press

Galev, G. \& Dabovikj - Anastasovska J. (2008) Облигачионо право [Law of Obligations]. Skopje: Iustinainus Primus Law Faculty - Skopje.

Radišić, J. (2004). Law of Obligations [Облигаџионо право]. Belgrade: Nomos

Werro, F. \& Palmer V.V. \& Hahn A. (2004). Synthesis and survey of the cases and results. Werro, F., Palmer, V.V. (eds.), The Boundaries of Strict Liability in European Tort Law. Durham: Carolina Academic Press.

Zdraveva, N. (2018). "Углед и чест" или „навреда и клевета" одговорноста наспроти законското уредување ["Reputation and Honour" or "Slander and Libel" - the libality vis-à-vis the legislative regulation]. Ristova - Aasterud, K. (ed.) Annuary of the Iustinainus Primus Law Faculty in honour of prof. d-r Miodrag Micajkov, vol. 58. Skopje: Iustinainus Primus Law Faculty

Zhivkovska, R. (2007). Општ дел на граѓанското право - воведни теми 2 - (субјективитетот на физичките лииа) [General Part of the Civil Law - Introductory Topics 2 - (Personhood of the Natual Persons]. Skopje: Napredok

\section{International Conventions}

Convention on the Rights of the Child, Adopted and opened for signature, ratification and accession by General Assembly resolution 44/25 of 20 November 1989 entry into force 2 September 1990, in accordance with article 49

\section{Foreign Legislation}

Bürgerliches Gesetzbuch in der Fassung der Bekanntmachung vom 2. Januar 2002 (BGBl. I S. 42, 2909; 2003 I S. 738), das zuletzt durch Artikel 10 des Gesetzes vom 30. März 2021 (BGBl. I S. 607); available at https://www.gesetze-im-internet.de/englisch_bgb/ [last access 01/05/2021] 
Law on Obligations (“Official Gazette of the Republic of Croatia" 35/05, 41/08, 125/11, 78/15, 29/18); available at https://zakon.hr/z/75/Zakon-oobveznim-odnosima [last access 01/05/2021]

Law on Obligations ("Official Gazette of SFRY" no. 29/78, 39/85, 45/89, "Official Gazette of Federal Republic of Yugoslavia" no. 31/93, "Official Gazette of Serbia and Montenegro" no. 1/2003, "Official Gazette Republic of Serbia" no.18/2020); available at https://www.paragraf.rs/propisi/zakon_o_obligacionim_odnosima.ht $\mathrm{ml}$ [last access 01/05/2021]

Law on Obligations of the Federation of Bosnia and Herzegovina ("Official Gazette of SFRY" no. 29/78, 39/85, 45/89, "Official Gazette of the Republic of Bosnia and Herzegovina" no. 2/1992, 13/1993 and 13/1994 and "Official Gazette of the Federation of Bosnia and Herzegovina" no. 29/2003 and 42/2011); available at https://www.paragraf.ba/propisi/fbih/zakon-o-obligacionimodnosima.html [last access 01/05/2021]

Law on Obligations ("Official Gazette of Montenegro" no. 47/2008, 4/2011, 22/2017); available at https://www.paragraf.me/propisicrnegore/zakon-o-obligacionim-odnosima.html [last access 01/05/2021]

Code of Obligations ("Official Gazette of Republic of Slovenia" no. 97/07, official consolidated version 64/16 - decision of the Constitutional $\begin{array}{llll}\text { Court 20/18 } & - & \text { OROZ631); }\end{array}$ http://www.pisrs.si/Pis.web/pregledPredpisa?id=ZAKO1263 [last access 01/05/2021]

\section{National Legislation}

Law on Obligations ("Official Gazette of Socialist Federative Republic of Yugoslavia" no. 29/78, 39/85 and 57/89)

Law on Obligations 8/2001; 4/2002; 5/2003; 84/2008; 81/2009 and 161/2009)

Law on Civil Liability for Insult and Defamation (,Official Gazette of the Republic of Macedonia" no.143/2012)

Law on Labour Relations ("Official Gazette of the Republic of Macedonia" nos. 62/2005, 106/2008, 161/2008, 114/2009, 130/2009, 149/2009, 50/2010, 52/2010, 124/2010, 47/2011, 11/2012, 39/2012, 13/2013, 25/2013, 170/2013, 187/2013, 113/2014, 20/2015, 33/2015, 72/2015, 129/2015, 27/2016 and 120/2018 and "Official Gazette of the Republic of North Macedonia" nos. 110/2019 and 267/2020)

Law on Family ("Official Gazette of the Republic of Macedonia" no. 153/2014, $104 / 2015$ and $150 / 2015$ )

\section{Case-law}

Judgment of the Supreme Court of the Socialist Republic of Macedonia, Rev. No. $283 / 80$ of 17.06 .1980 
Principle Position no. 3/85 established at the 28th Joint Session of the Federal Court, the Supreme Courts of the Republics and the Provinces and the Supreme Military Court, held on 6-7. 11. 1985

Deliberation of the Civil and Civil-Trade Divisions of the Federal Court, the Supreme Courts of the Republics and the Provinces and the Supreme Military Court, held on 15 and 16.10.1986

Judgment of the Primary court in Bjelovar, Gz. no. 281/91 of 09.01.1992

Judgment of the Supreme Court of the Republic of Macedonia, Rev. No. 139/97 of 08.07.1998

Judgment of the Supreme Court of Serbia, Rev.2261/98 of 20.05.1998 